\title{
Extract Gel of Chinese Petai Leaf (Leucaenaleucocephala) for Acute Wounds in Rats (Rattusnorvegicus)
}

\author{
Anis Ika Nur Rohmah*, Edi Purwanto and Vicky Nurdiansyah \\ Department of Nursing, Faculty of Health Science, University of Muhammadiyah Malang, Jalan. Bendungan Sutami \\ No. 188A, Malang, East Java, Indonesia
}

Keywords: Chinese petai leaf, acute wounds, rats.

\begin{abstract}
The many occurrences of acute injuries due to the surgical process or accident have a considerable risk of complications if not given appropriately. Chinese Petaileaves contains saponins, tannins, and flavonoids are useful for accelerating through the process of acute wound healing. In this study, extract Chinese Petai leaf made in gel preparations to be practical, sterile, and become the latest innovation. The purpose of this study was examined the extract gel Chinese Petai leaf effectively for the treatment of acute wounds to rats. This study used true-experimental design with a randomized control group posttest design as an approach. The samples in intervention group $(n=7)$ and control group $(n=6)$ used simple random sampling and for data was analyzed using Man Whitney test. The results indicated that the first group (Extract Gel Chinese Petai Leaf) and the second group (Normal Saline) had significant differences in the percentage of wound closure on the eighth day with the score $(\mathrm{p}=0.014)$. Difference in the percentage of wound closure was seen starting early in the epithelialization phase of acute wounds and more clearly on the eighth day. Extract gel of Chinese Petai leaf effectively accelerated the closure of wound acute stage II.
\end{abstract}

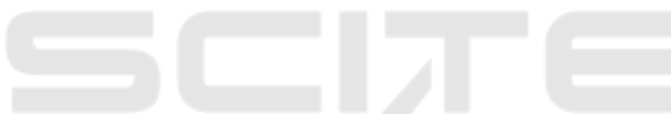

\section{INTRODUCTION}

Wounds come from trauma to the skin which is a condition where the continuity of the body's tissue continuation can disrupt to the normal functioning of the body (Damayanti, Pitriani, \& Ardhiyanti, 2013). According to the duration of healing, wounds are divided into 2 types, namely acute and chronic wounds. Acute wounds are wounds that heal according to the physiology of the wound healing process. Acute wounds can be caused by trauma suddenly or planned as during the surgical process. A chronic wound is a complication of an acute wound, which is where acute wound care is not appropriate (Wijaya, 2018).

Acute wounds have a high risk of complications if they do not get proper wound care. Complications of acute injuries can occur within 24 hours after the trauma. Several kinds of complications can occur in acute wounds, including bleeding, hematoma or tissue edema, dehiscence or not joining the wound edges, and infection (Wijaya, 2018). Infection In acute wounds can occur in the inflammatory phase. This can occur because of bleeding that is long enough (10-20 minutes), so that the blood supply in the inflammatory phase is greatly reduced and white blood cells do not reach the site of the wound (Peate $\&$ Glencross, 2015). Complications of acute wounds can also lead to amputation caused by an infection in the wound and sufferers who have risk factors for diabetes mellitus (Supriyadi, 2017).

Several factors influence wound healing, including: vascularization, age, and concomitant diseases. Vascularization affects because the wound requires a good circulatory condition. The speed of cell repair takes place in line with the growth or maturity of a person, but the aging process can reduce the speed of cell repair. While other diseases, such as anemia, diabetes mellitus and kidney disorders that can slow wound healing (Damayanti et al., 2013).

The national wound prevalence in Indonesia is $8.2 \%$. Comparison of the results of Riskesdas 2007 with Riskesdas 2013 showed an increase in wound prevalence from $7.5 \%$ to $8.2 \%$ (Trihono, 2013). The three most common types of injuries suffered were $70.9 \%$ abrasions; sprained $27.5 \%$, and torn wounds $23.2 \%$. Whereas in 2018 Riskesdas there was an increase in wound prevalence from $8.2 \%$ in 2013 to $9.2 \%$ in 2018 results (Riskesdas, 2018). 
Chinese Petai has a variety of chemical contents both in the seeds or leaves. The chemical content of old seeds in every 100 grams has 148 calories of calories, 10.6 grams of protein, 0.5 grams of fat, 26.2 grams of charcoal hydrate, 155 grams of calcium, $59 \mathrm{mg}$ of phosphorus, $2.2 \mathrm{mg}$ of iron , vitamin A 416 SI, vitamin B $10.23 \mathrm{mg}$, and vitamin C $20 \mathrm{mg}$. In the results of a study found that Chinese Petai leaf extract contains saponins, alkaloids, tannins, and flavonoids (Widyantoro \& Sugihartini, 2015). The saponin content contained in Chinese Petai leaves can be antibacterial (Pratiwi, Soetjipto, \& Hartini, 2014). Flavanoid is a compound derived from flavone compounds. Flavanoid is a protein structure that plays a role in the process of wound healing and can be a cleanser for wounds (Praja \& Oktarlina, 2016).

Chinese Petai leaves have a variety of chemical contents, where the content can be used as an ingredient in the treatment of new wounds and swelling by pounding or chewing. Furthermore, the results of leaves that have been smooth are immediately affixed to the wound or swollen area (Thomas, 2007). In another study showed that the scouring of 30 grams of Chinese Petai leaves provided significant healing results with the most length of clean wound healing on day 5 , while the length of clean wound healing using povidone iodine was $10 \%$ on the 8 th day (Rahmawati, 2015).

The gel is a semi-solid preparation consisting of organic and inorganic suspensions. Gel for topical use can immediately melt if it comes into contact with the skin and will form a layer. Absorption of the skin in gel form is better than other ointment preparations (Yanhendri \& Yenny, 2012). Gelshaped ointments have finer consistency, are generally liquid and contain little or no mucosa as a base (Elmitra, 2017).

Treatment using Chinese leaves with crushed or chewed cannot last long and must be made every day. This can make people less interested in using it and choosing a more practical way. Therefore, an alternative is needed in the presentation of Chinese Petaileaves so that it is easy to use. On this occasion, the researchers wanted to know the effectiveness of Chinese Petaileaf extract gel for the treatment of incision wounds in rats. The presence of Chinese Petaileaf extract gel is expected to simplify wound care that can be used at any time, is more effective, and is practical for storage as supplies.

\section{METHODS}

This study is an experimental study using a true experimental research design and using a randomized control group posttest design approach. This study consisted of 2 groups, namely the intervention group $(n=7)$ who were treated with wound care using Chinese Petaileaf extracts, and the control group $(n=6)$ who were given standard treatment using $0.9 \% \mathrm{NaCl}$.

The sampling technique used is simple random sampling. The method of taking the sample is by drawing, so it is chosen randomly according to the experimental design to place the rat in 2 groups (Surahman, Rachmat, \& Supardi, 2016).

White rat used in this study must meet the following experimental animal requirements: (1) White male rats (rattusnorvegicus), (2) 2-3 months old, (3) White rat with normal body weight of 160 grams, (4) active (healthy) moves, and (5) have never been used as experimental animals in other studies.

In this study, ethical information was obtained No.E.5.a / KEPK-UMM / II / 2019 from the UMM Health Research Ethics Commission. This research was conducted at the Pharmacology Laboratory of the Faculty of Medicine, University of Muhammadiyah Malang. When the research was carried out on 05 to 12 April 2019.

The dose of Chinese Petaileaf extract gel was $0.006 \mathrm{~g}$ each time applying $1 \mathrm{~cm} 2$ to the wound. Measurement of gel dosage using micro scales that can read the mass of objects under 1 gram and adjusted to changes in wound area until the gel is applied evenly. Giving Chinese Petaileaf extract gel is done 2 times a day in the morning at 07.00 and in the afternoon at 16.00 (Andrie \& Sihombing, 2015).

Experimental animals adapted in rat cages were given the same treatment for 7. During adaptation, all try animals looked healthy, actively moving, and nothing stressed. When intervening, animals try to get food and drink according to their needs.

The data collection stage was carried out by measuring the area of the wound on the 4th day and the 8th day. Measuring the area of the wound using image $\mathbf{J}$ software. The wound image is taken by attaching mica paper over the wound, then draw by following the edge of the wound using a marker and after that, the picture is photographed and inserted into the image $\mathrm{J}$ application.

The resulting wound area is then entered into the formula for wound closure percentage. The formula for measuring wound closure: 
Percentage of wound closure $=(\mathrm{AO}-\mathrm{AD}) / \mathrm{AO}$ $\mathrm{x} 100 \%$ (1).

Information:

$\mathrm{AO}=$ area of the wound on day 0 .

$\mathrm{AD}=$ area of the wound on the day after treatment (Avinash et al., 2016).

\section{RESULTS AND DISCUSSION}

Based on the figure 1, the picture shows that all white rat animals have been measured the percentage of wound closure on day 4 in group 1 (intervention) with an average value of $14.6 \%$, and in group 2 (control) with a mean value an average of $9.7 \%$. On the 8th day in group 1 with an average value of wound closure was $81.2 \%$ and in group 2 it was $62.9 \%$. There was an increase in the percentage of initial wound closure on day 4 by 14.6 in group 1 to $81.2 \%$ on day 8 , whereas in group 2 the percentage of wound closure initially on day 4 was $9.7 \%$ to $62.9 \%$ on the 8 th day.

The results of the study on the percentage of wound closure on day 4 obtained from the SPSS output found that the significant value (p), in the Man Whitney statistical test the significance value of 0.628 where the value is greater than the value of $\alpha$ (0.05). The results of these calculations can be concluded that there was no significant difference in the percentage of wound closure in the intervention group given Chinese Petai leaf extract gel and in the control group given normal saline for acute wounds in the rat on the 4 th day.

The results of the study on the percentage of wound closure on the 8th day obtained from the SPSS output found that the significant value (p), in the man whitney statistical test the significance value of $p=0.014$ where the value is smaller than the value of $\alpha(0.05)$. The results of these calculations can be concluded that there is a significant difference in the percentage of wound closure in the intervention group given Chinese Petaileaf extract gel and in the control group given normal saline for acute wounds in rats on the 8th day.

Based on the results of research in the intervention group that was given Chinese Petaileaf extract gel showed that the wound healing process went normal. None of the wound healing stages were missed and there were no interruptions in each process, which was proven in the intervention group that there were no signs of wound infection. This proves the theory revealed by Pratiwi (2014) and Yuliarti (2009) that the saponin and tannin content in Chinese Petai leaves that function as anti-bacterial and anti-inflammatory properties can prevent infection so that the inflammatory process is not interrupted.

In the intervention group, the results of the study showed the percentage of wound closure on day 4 with an average value of $14.6 \%$, the condition of the wound had begun to epithelialization phase, and no signs of infection were found. Reassessment was carried out on the 8th day which found that the percentage of wounds had increased with an average value of $81.2 \%$, a good wound condition which was proven that the scab (necrose) had been peeled off on the 6th day so that a new layer of skin had been seen.

In the control group, the results of the study were the percentage of wound closure on day 4 with an average value of $9.7 \%$, the condition of the wound had begun to epithelialization phase, and found signs of infection in the form of edema. Reassessment was conducted on the 8th day which found that the percentage of wounds had increased with an average value of $62.9 \%$, found scabs (necrose) had only begun to peel on the 8th day.

In the control group given normal saline showed that the wound healing process proceeded normally, even though on the 3rd and 4th day there were signs of infection in the form of edema in some rats. That is, not until there are severe complications that become chronic wounds. Wounds in the control group can heal according to the process of healing acute wounds. In accordance with other studies which state that irrigation wounds using normal saline routinely can reduce the incidence of surgical wound infections. Most liquids used in addition to normal saline show inconsistencies as wound irrigation fluid (Pieper et al., 2018).

During the study, the rat wound condition in the intervention group healed faster, visible from the polymerization phase faster than the control group and visible signs of infection in the form of edema in the wound area in 3 rats in the control group on days 3 and 4 . In the intervention group, there was 6 rats with a scab (necrose) covering the skin to peel off earlier in the 6th day. Whereas in the control group the new necrose peeled off on the 8th day. Characteristics of scab (necrose) in the rat have a clear color and when peeling the wound dries immediately does not cause wound infection. 
Figure 1: Change in percentage of wound closure on day 4.

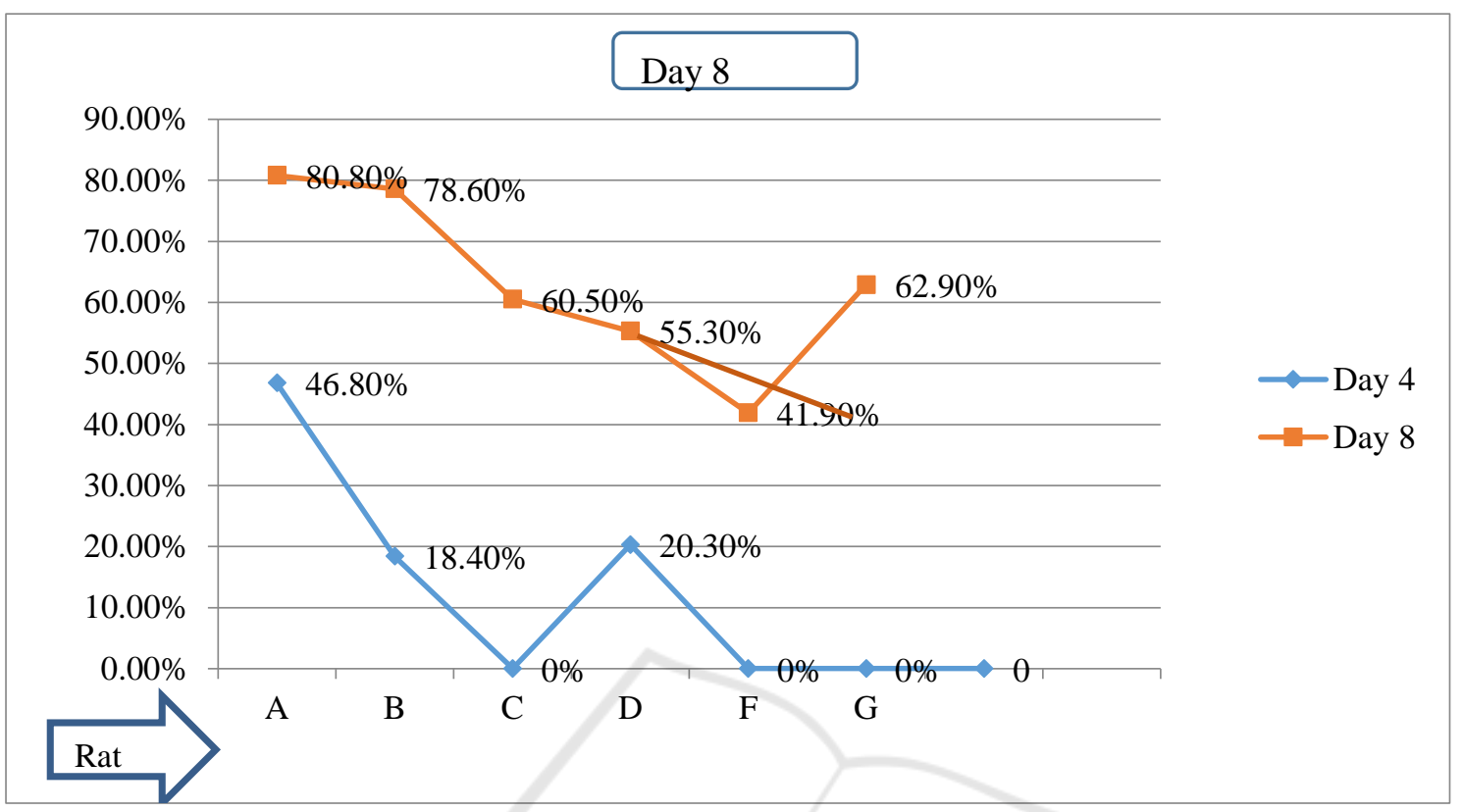

Figure 2: Change in percentage of wound closure on day 8.

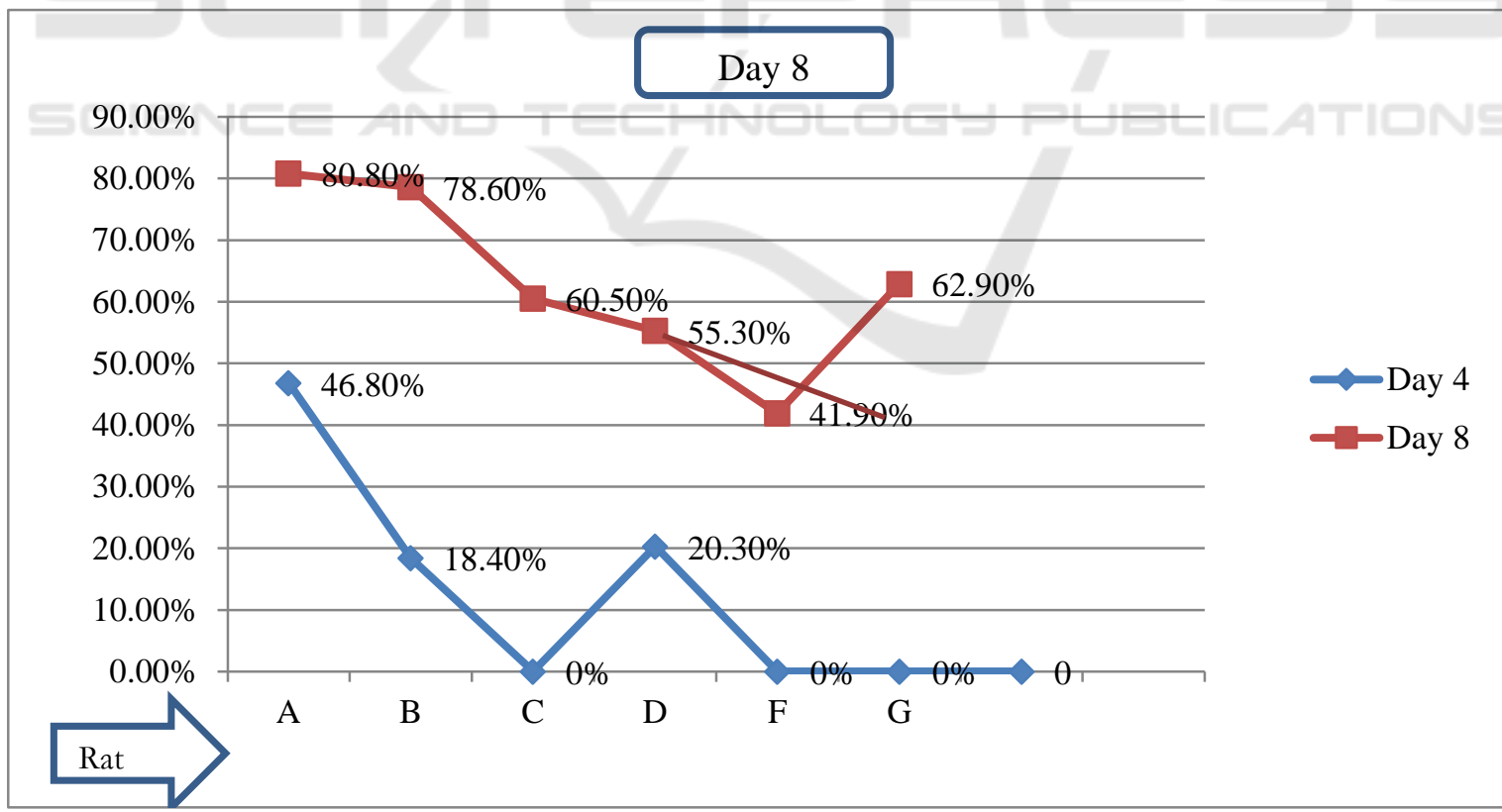

According to (Aponno et at., 2014) in (Fitriani, 2016) explains that the speed of the formation of a scab indicates the speed of wound healing. This indicates the occurrence of the growth of new cells in the skin so that it helps accelerate the release of 
scabs and accelerate the contraction of the wound edges.

The above results prove that Chinese Petaileaves which have useful ingredients for the wound healing process is proven to accelerate the polymerisation process as seen from the percentage of wound closure with an average value of $81.2 \%$ on the 8th day. By the conceptual framework expected from the content of flavonoids, saponins, and tannins which can accelerate proliferation. These results are consistent with Tsala, Nga, Thiery, Bienvenue, dan Theophile (2015) research which explains that the content of flavonoids, tannins, and saponins can be antioxidants and accelerate the process of epithelialization of incision wounds. Widyantoro dan Sugihartini (2015) stated that in each extract of Chinese Petaileaf contains saponin, alkaloid, tannin, and flavonoid compounds. Saponins that are abundant in the roots and leaves can provide many benefits because it has anti-bacterial and antiviral (Mardiana, 2012). Flavonoids, tannins, and saponins can also be antibacterial and can accelerate the contraction of wound edges (Begashaw et al., 2017).

Flavonoids also function as antioxidants and protect collagen tissue (Yuliarti, 2009). This is in line with other studies which explain that the flavonoid content in hesperidin can accelerate the wound healing process in the rat (Li et al., 2018). Other studies on latex jatropha curcas leaves which contain flavonoids, tannins and saponins are effective in accelerating the wound healing process (Balqis et al., 2018). In another study also explained the effectiveness of flavonoids from butea monosperms showed significant results in the process of wound healing (Muralidhar et al., 2013).

Chinese Petaileaf extract gel which was used for wound care during the research proved that after it was applied it could immediately melt and fill the wound area which could make the active ingredient of Chinese Petaileaf absorbed into rat skin. Wounds given by Chinese Petaileaf extract gel can also be protected from contamination. Following the theory (Elmitra, 2017) which explains that gels for topical use can immediately melt when in contact with the skin and will form a layer.

The results of this study which aims to determine the percentage of wound closure in line with other studies show that the scouring of 30 gram Chinese Petaileaves provides significant healing results with the most length of clean wound healing on day 5 , while the length of clean wound healing using $10 \%$ providone iodine at 8 th day (Rahmawati, 2015). The results of this study indicate a higher percentage of wound closure with an average value of $81.2 \%$ on the 8th day when compared to other studies of the combination of water-oil ointment cork fish extract which obtained a $50 \%$ percentage of open wound closure stadium II on the 8th day (Andrie and Sihombing, 2015).

During the study, a limitation that could not be avoided from the research was that there was one mouse that died in the control group. As per the code of ethics of animal studies, dead rats are buried. In addition, necrosa on some rat peel prematurely due to friction in places around the cage.

\section{CONCLUSIONS}

In this study, a significant difference in the percentage of wound closure $(p=0.014)$ using Chinese Petaileaf extract gel compared with normal saline on the 8th day. In the intervention group, there were no signs of infection and necrose was more rapid peeling. This proves that Chinese Petaileaf extract gel can accelerate the process of closing the acute wound in the rat. Further research is needed to get accurate results on human samples so that the Chinese Petaileaf extract gel can be proven to accelerate the process of wound closure in humans. Future studies are expected to be able to control the limitations of this study in the form of the influence of friction around the place which results in peeling off scabs prematurely.

\section{REFERENCES}

Andrie, M. and Sihombing, D. (2015) 'Efektivitas Sediaan Salep yang Mengandung Ekstrak Ikan Gabus ( Channa striata ) pada Proses Penyembuhan Luka Akut Stadium II Terbuka pada Tikus Jantan Galur Wistar The Effectiveness of Snakehead ( Channa striata) Extract- Containing Ointment on Healing P', Pharm Sci Res, pp. 88-101.

Balqis, U. et al. (2018) 'Angiogenesis Activity of Jatropha Curcas L. Latex in Cream Formulation on Wound Healing in Mice', Veterinary World, 11(9).

Begashaw, B. et al. (2017) 'Methanol Leaves Extract Hibicus Micranthus Linn Exhibited Antibacterial and Wound Healing Activities', Complementary and Alternative Medicine, 17(337).

Elmitra (2017) Dasar Dasar Farmasetika dan Sediaan Semi Solid. 1st edn. Yogyakarta: Deepublish.

Fitriani, N. (2016) Uji Aktivitas Gel Etil PMetoksisinamat Terhadap Penyembuhan Luka Terbuka Pada Tikus Putih (Rattus norvegicus) Jantan Galur Sprague Dawley.

Li, W. et al. (2018) 'Hesperidin, A Plant flavanoid Accelarated The Cutaneous Wound Healing in 
Streptozotocin-Induced Diabetics Rats: Role of TGHB/SMADS and ANG-1/TIE-2 Signaling Pathways', EXCLI Journal, 17, pp. 399-419.

Mardiana, L. (2012) Daun Ajaib Tumpas Penyakit. Jakarta: Penebar Swadaya.

Muralidhar, A. et al. (2013) 'Wound healing activity of flavonoid fraction isolated from the stem bark of Butea monosperma ( Lam ) in albino wistar rats', J. Exp. Bio, 3(6), pp. 1-6.

Pieper, D. et al. (2018) 'The Role of Saline Irrigation Prior to Wound Closure in The Reduction of Surgical Site Infection: Protocol for a Systematic Reviev and Meta Analysis', 7(158).

Pratiwi, M., Soetjipto, H. and Hartini, S. (2014) Isolasi Saponin Daun Petai Cina ( Leucaena leucocephala (Lam.) De Wit.) dan Aplikasinya Sebagai Pembusa Alami Serta Antibakteri Dalam Shampo.

Rahmawati, I. (2015) 'Perbedaan Efek Perwatan Luka Menggunakan Gerusan Daun Petai Cina ( Leucaena glauca , Benth ) dan Povidon Iodine $10 \%$ Dalam Mempercepat Penyembuhan Luka Bersih Pada Marmut ( Cavia porcellus )', Jurnal Wiyata, 2, pp. 7378.

Tsala, D. E. et al. (2015) 'Evaluation of the Antioxidant Activity and the Healing Action of the Etanol Extract of Calotropis Procera Bark Against Surgical Wounds', Intercultural Ethnopharmacology, 4(1).

Widyantoro, O. B. and Sugihartini, N. (2015) 'Uji Sifat Fisik dan Aktivitas Ekstrak Daun Petai Cina ( Leucaena glauca, Benth ) Dalam Berbagai Tipe Basis Salep Sebagai Obat Luka Bakar', Media Farmasi, 12, pp. 48-60.

Yuliarti, N. (2009) A to Z Food Supplement. 1st edn. Edited by B. Rini. Yogyakarta: ANDI.

Andrie, M. and Sihombing, D. (2015) 'Efektivitas Sediaan Salep yang Mengandung Ekstrak Ikan Gabus ( Channa striata ) pada Proses Penyembuhan Luka Akut Stadium II Terbuka pada Tikus Jantan Galur Wistar The Effectiveness of Snakehead ( Channa striata ) Extract- Containing Ointment on Healing P', Pharm Sci Res, pp. 88-101.

Balqis, U. et al. (2018) 'Angiogenesis Activity of Jatropha Curcas L. Latex in Cream Formulation on Wound Healing in Mice', Veterinary World, 11(9).

Begashaw, B. et al. (2017) 'Methanol Leaves Extract Hibicus Micranthus Linn Exhibited Antibacterial and Wound Healing Activities', Complementary and Alternative Medicine, 17(337).

Elmitra (2017) Dasar Dasar Farmasetika dan Sediaan Semi Solid. 1st edn. Yogyakarta: Deepublish.

Fitriani, N. (2016) Uji Aktivitas Gel Etil PMetoksisinamat Terhadap Penyembuhan Luka Terbuka Pada Tikus Putih (Rattus norvegicus) Jantan Galur Sprague Dawley.

Li, W. et al. (2018) 'Hesperidin, A Plant flavanoid Accelarated The Cutaneous Wound Healing in Streptozotocin-Induced Diabetics Rats: Role of TGHB/SMADS and ANG-1/TIE-2 Signaling Pathways', EXCLI Journal, 17, pp. 399-419.

Mardiana, L. (2012) Daun Ajaib Tumpas Penyakit.
Jakarta: Penebar Swadaya.

Muralidhar, A. et al. (2013) 'Wound healing activity of flavonoid fraction isolated from the stem bark of Butea monosperma ( Lam ) in albino wistar rats', J. Exp. Bio, 3(6), pp. 1-6.

Pieper, D. et al. (2018) 'The Role of Saline Irrigation Prior to Wound Closure in The Reduction of Surgical Site Infection: Protocol for a Systematic Reviev and Meta Analysis', 7(158).

Pratiwi, M., Soetjipto, H. and Hartini, S. (2014) Isolasi Saponin Daun Petai Cina ( Leucaena leucocephala (Lam.) De Wit.) dan Aplikasinya Sebagai Pembusa Alami Serta Antibakteri Dalam Shampo.

Rahmawati, I. (2015) 'Perbedaan Efek Perwatan Luka Menggunakan Gerusan Daun Petai Cina ( Leucaena glauca , Benth ) dan Povidon Iodine $10 \%$ Dalam Mempercepat Penyembuhan Luka Bersih Pada Marmut ( Cavia porcellus )', Jurnal Wiyata, 2, pp. 7378.

Tsala, D. E. et al. (2015) 'Evaluation of the Antioxidant Activity and the Healing Action of the Etanol Extract of Calotropis Procera Bark Against Surgical Wounds', Intercultural Ethnopharmacology, 4(1).

Widyantoro, O. B. and Sugihartini, N. (2015) 'Uji Sifat Fisik dan Aktivitas Ekstrak Daun Petai Cina ( Leucaena glauca , Benth ) Dalam Berbagai Tipe Basis Salep Sebagai Obat Luka Bakar', Media Farmasi, 12, pp. 48-60.

Yuliarti, N. (2009) A to Z Food Supplement. 1st edn. Edited by B. Rini. Yogyakarta: ANDI. 